\title{
Kamu Yönetiminde Kamu Yararının Gerçekleştirilmesinde Adaletin Önemi
}

\section{Ömer ÇAMUR ${ }^{1}$}

$\ddot{O} z$

Kamu yönetimi devletin yürütme organı olarak vatandaşların ihtiyaçlarını karşılamak amacıyla hizmet sunan önemli bir olgudur. Kamu yönetimi hizmet sunumu sırasında kamu yararını dikkate almak zorundadır. Kamu yararı ise genel bir ifade ile kamu yönetiminin eylem ve işlemlerinde vatandaşların çıkarları doğrultusunda faaliyet göstermesini ifade etmektedir. Kamu yönetiminin varlık nedeni olan kamu yararının başarılı bir şekilde gerçekleştirilebilmesi, bireysel yaşamdan toplumsal yaşama kadar etkili olan ve devletin bir bütün olarak meşruiyet kazanmasını sağlayan önemli bir etkendir. Kamu yararının başarılı bir şekilde gerçekleştirilmesi ise adaleti gerekli kılmaktadır. Zira tüm tarihsel dönemlerde en üstün erdem ve amaç olarak kabul edilen adalet, bireysel yaşamdan toplumsal yaşama ve nihayetinde devlet yaşamına kadar etkili olan ve tüm kamusal hizmetlerde toplumsal çıkarların dikkate alınmasını gerekli kılan bir kavramdır. Dolayısıyla kamu yararının başarılı bir şekilde gerçekleştirilmesinde adalet oldukça önemli bir yere sahiptir. Yapılan bu çalışmada öncelikle kamu yönetimi açısından kamu yararı kavramı açıklanacak, devamında adalet kavramının ne olduğu üzerinde durulacak ve nihayetinde kamu yönetiminde kamu yararının başarılı bir şekilde gerçekleştirilmesinde adaletin önemi ortaya konmaya çalışılmıştır.

Anabtar Kelimeler: Kamu Yönetimi, Kamu Yararı, Adalet

\section{The Importance of Justice in Achieving Public Interest in Public Administration}

\begin{abstract}
Public administration is an important phenomenon that serves to meet the needs of citizens as an executive organ of the state. Public administration must consider public interest when delivering services. The public interest generally means that in its actions and operations, public administration acting with respect to the interests of the citizens. To be successfully able to realize the public benefit which is the reason for public administration is a major factor that has implications from individual to social life, and provides the state with legitimacy as a whole. Achieving public interest makes justice essential, because justice, deemed as the highest virtue and goal in all historical periods, is a concept that is influential from individual to society and ultimately to public life, and necessitates considering social interests in all public services. Thus, justice plays a significant role in achieving public interest. This study attempts first to explain the concept of the public interest in terms of public administration, second to discuss the concept of justice and finally, to indicate the significance of justice in achieving public interest in public administration.
\end{abstract}

Key Words: Public Administration, Public Interest, Justice

\section{Atıf İçin / Please Cite As:}

Çamur, Ö. (2020). Kamu yönetiminde kamu yararının gerçekleştirilmesinde adaletin önemi. Manas Sosyal Araştirmalar Dergisi, 9(1), 605-614.

Geliş Tarihi / Received Date: 04.02.2019

Kabul Tarihi / Accepted Date: 27.06.2019

\footnotetext{
${ }^{1}$ Dr. Öğr. Üyesi-Bingöl Üniversitesi Sağlık Hizmetleri Meslek Yüksekokulu, ocamur@bingol.edu.tr ORCID: 0000-0001-6447-1475
} 


\section{Giriş}

Kamu yararı kamu yönetiminin eylem ve işlemlerinin vatandaşlar adına yerine getirilmesinde ve dolaysıyla toplum tarafından meşru kabul edilmesinde doğrudan etkili olan önemli bir kavramdır. Geniş bir kavram olan kamu yararı tarihin her döneminde devletlerin temel amaçlarından biri olmuştur. Çünkü ortak ihtiyaçlarını gidermek amacıyla bir araya gelen insanların oluşturmuş oldukları devletin ve onun icracısı konumunda bulunan kamu yönetiminin temel varlık nedeni kamu yararının sağlanmasıdır.

Kamu yönetimi devletin vatandaşlara yansıyan yüzüdür. Halk, kamu yönetiminin faaliyetleri doğrultusunda devletin eylem ve işlemlerini adaletli veya adaletsiz olarak değerlendirmektedir. Vatandaşa hizmet sunma konusunda belirli olan genel ilkelerin kamu yönetimi tarafindan dikkate alınması, kamu yönetiminin başarılı bir şekilde hizmet sunması açısından oldukça önemlidir. Bu ilkelerden en önemlisi ise adalettir. Adaletin bulunmadığı bir yönetimde kararların ve uygulamaların vatandaşların beklediği amaç doğrultusunda kullanılması oldukça zordur. $\mathrm{Bu}$ durum beraberinde kamu yararının kamu yönetimi tarafindan ihmal edilmesi gibi önemli bir soruna neden olabilmektedir.

Kamu yararı ile adalet arasında tarihsel bir ilişki bulunmaktadır. Tarihsel süreç içerisinde kamu yararı çoğu kez adalet olarak tanımlanmış ve adalete kamu yararının gerçekleştirilmesi amacıyla bakılmıştır. Bireysel anlamda yetkinlikten toplumsal yetkinliğe ulaşmada temel kriter olan adalet, toplumsal ihtiyaçların karşılanmasında ve ortak yararın sağlanmasında başvurulması gereken en önemli unsurdur. Dolayısıyla kamu yönetiminin kamu yararı doğrultusunda faaliyet göstermesi adaleti gerekli kilmaktadır.

Bu bilgiler ışı̆̆ında yapılan bu çalışmada öncelikle kamu yararı kavramı tanımlanarak kamu yönetimi açısından incelenecek ve adaletin ne olduğu detaylı bir şekilde açıklanmaya çalışılacaktır. Çalışmanın devamında ise kamu yönetiminde kamu yararının başarılı bir şekilde gerçekleştirilmesinde adaletin önemi ortaya konmaya çalışılacaktır.

\section{Kamu Yarar1}

Birçok düşünür tarafindan devletin idaresinde ve yöneticilerin değerlendirilmesinde başlıca unsur sayılan kamu yararı kavramı, birçok alanda tartışılan bir kavram olmakla birlikte tanımı noktasında henüz bir birliğin sağlanamadığı ve hakkında oldukça farklı görüşlerin öne sürüldüğü bir kavramdır (Birinci, 2009, s. 135; Dik, 2005, s. 2). Dolayısıyla kamu yararı zamana, mekana, hizmetten faydalananlara ve hizmetin türüne göre farklılaşan bir nitelik ihtiva etmektedir (Göven, 1999, s. 253). Bu durumun temelde iki nedeni bulunmaktadır. Bunlardan ilki, kamu yararı kavramının geniş kapsamlı bir kavram olarak hukuk ve yönetimi aşan ve ahlak, felsefe, sosyoloji gibi alanlarda da incelenen bir kavram olmasıdır. Diğer bir nedeni ise kavramın sınırlarının belli olmaması ve çok esnek bir yapıda olmasıdır. Günümüzde kamu yararı kavramı, sahip olduğu bu çeşitliliğe ve belirsizliğe rağmen değişen dünyada gün geçtikçe gelişmiş ve kendisini sürekli yenileyerek kapsama alanını insan ihtiyaçları doğrultusunda genişletmiştir (Koç, 2014, s. 23).

Kamu yararı kavramının kamu yönetimi açısından önemi günümüz dünyasında daha da önemli bir hal almıştır. Klasik yönetim anlayışında sınırları yasalar ile çizilmiş olan kamu yararı kavramı, ortaya çıkan yeni kamu yönetimi, yeni kamu işletmeciliği, yönetişim ve yeni kamu hizmeti gibi yönetsel anlayışlarda temel unsur olarak kendisini göstermiş ve kamu yönetiminin temel gayesi halini almıştır. Dinamik bir yapı arz eden kamu yararı, artık kamu yönetiminin vazgeçilmez bir unsuru olarak varlı̆̆ını güçlendirmiş durumdadır.

Kamu yararı ile ilgili birçok tanıma ulaşmak mümkündür. Kamu yararı kavramı kamu yönetimi sözlüğünde, "kamu yönetiminin eylem ve işlemlerinde yöneldiği ve toplumun bir kesiminin ya da tümünün yararını kollamaya dönük, temel ve genel hedef" şeklinde tanımlanmıştır (Bozkurt vd., 2008, s. 132-133). Erdoğan’a (2013, s. 265) göre kamu yararı, "bir topluluğun paylaşılan (ortak) çıkarlarını ifade eder". Yayla' ya (2010, s. 71) göre kamu yararı, "muhtelif kişi ve grupların yararları arasındaki bir dengeyi" ifade etmektedir. Keleş'e (2000, s. 223-224) göre kamu yararı, "toplum içinde önlenemez yarar çatışmalarında, çoğunluğun azınlı̆a; sayıca çok olan grubun çıkarlarının, sayıca az olan kişilerin çıkarlarına üstün tutulması" anlamina gelmektedir. Eryılmaz'a (2015, s. 10) göre kamu yararı, "toplumun ve devletin ihtiyaçları ile ilgili olan ve o ihtiyaçları karşılayan, halka ve devlete istifadeler temin eden menfaatleri anlatır”. Özdemir'e (2008, s. 180) göre ise kamu yararı, halkın ihtiyaç duyduğu her türlü mal ve hizmetin kamu yönetimi veya bürokrasisi tarafından sunulmasıdır. 
Kamu yararı kavramı yerine literatürde genellikle "toplumsal refah", "ortak iyilik", "toplum yararı", "toplumsal esenlik" ve "genel yarar" gibi kavramların kullanıldığı görülmektedir. Bu kavramların ortak yönünü, hepsinin kişisel menfaatten farklı ve onun üstünde ya da dışında bir yararı ifade etmesidir (Sezer, 2008, s. 157).

Esasen kamu yararı, tanım zorluğundan dolayı işlevleri ile şekillenen ve ne olduğu ortaya konabilen bir kavramdır. Bu açıdan kamu yararı, devletin doğrulamasını yapmak amacıyla kullanılır. Yine kamu yararı yönetimde uygulanan özel kuralların uygulama alanlarının belirlenmesinde ve insan hakları alanında yapılan sınırlandırmalarda başvurulan temel ölçüt olarak geniş bir alanı kapsamaktadır. Dolayısıyla kamu yararı kavramı herhangi bir faaliyetin kamu faaliyeti veya devlet olduğunun temel göstergesidir (Akıllıŏlu, 1988, s. 3). Ayrıca kamu yararı sadece devletin doğrulanması için değil, kamusal işlemlerin hukuka uygunluğu açısından da önemli bir kavramdır. Yani kamu yararı, kamu yönetiminin gerçekleştirmiş olduğu eylem ve işlemlerinin hukuk düzenine uygunluğunun ölçülmesinde de kullanılan bir ölçüttür (Saraç, 2002, s. 16). Kamu yararının sahip olduğu bu işlevler kavramın ne olduğu konusunda önemli fikirler sunmaktadır.

Herkesi tatmin edecek ortak bir tanıma ulaşılmayan kamu yararı kavramı konusunda ortak fikir, kavramın sınırlarının ve tanımının belirlenmesinin zor olduğudur. Bu nedenle yazarların bir kısmı kamu yararı kavramını "bulanık" ve "öznel" olarak vasıflandırmaktadır. Bazıları da kamu yararı kavramının içeriğinin veya özünün önceden belli olmadığı ve sadece biçimi açısından tanımlanabileceğini ifade etmektedir. Diğer bazı yazarlar ise kavramı adaletli davranmanın bir çabası olarak nitelendirmekte ve hukuksal düzende kamu yararı kavramı ile ilgili bir tanımın yapılmasını kavramın dinamik yapısına ters düşeceğini belirtmektedir. Bu düşüncelerin yanı sıra kamu yararı kavramını bilimsel analize dayanıklı olmayan ve "akıl dışı bir masal" olarak devletin veya iktidarın pekiştirilmesinden öteye geçmeyen bir kavram olduğu da iddia edilmektedir (Göven, 1999, s. 7-8). Kamu yararı kavramının tanımlanmasının güç olduğunu elbette kabul etmek gerekir. Ancak kavramın toptan reddedilmesi bilimsel bir yaklaşımdan uzaklaşmayı beraberinde getirmektedir. Zira kamu yararı kavramı devletin veya kamu yönetiminin oluştuğu ve insanların ortak yarar düşüncesi etrafinda birleştiği dönemden beri varlığını sürdüren ve devletin ve kamusal faaliyetlerin öncülüğ̈̈nde somutlaşabilen bir kavramdır. Dolayısıyla kamu yararını bir hayal olarak yok saymak kamu yönetiminin faaliyetlerinin temel amaçlarından biri olan ortak yararı göz ardı etmektir (Dik, 2005, s. 3).

Kamu yararı ile ilgili verilen bu bilgiler ışı̆̆ında ifade edilebilir ki, kamu yönetiminin genel amacını kamuya yararlı olmak oluşturmaktadır. Dolayısıyla kamu yönetimi kamu yararı için vardır (Aydın, 2016, s. 45; Parlak ve Doğan, 2016, s. 35). Kamu yönetimine yönelik bu temel yaklaşım, kamu görevlilerinin davranışlanında etkili olan temel ilkenin kamu yararı olmasını sonuç vermiştir. Buna göre kamu görevlerinin aldıkları kararlarda ve bulundukları eylemlerde kamu yararını temel ölçüt olarak kabul etmeleri gerekmektedir (Birinci, 2009, s. 133).

Devletin yürütme gücüne karşıllk gelen kamu yönetimi, kamu yararını gerçekleştirmek ve vatandaşların ihtiyaç duyduğu mal ve hizmetleri üretmek için faaliyet göstermektedir. Devletin yerine getirmekle görevli bulunduğu faaliyetleri adalet, güvenlik, sağlık, eğitim, sosyal güvenlik ve belediye hizmetleri gibi geniş bir kapsamda incelemek mümkündür. Bu hizmetler büyük oranda kamusal ya da yarı kamusal nitelikteki hizmetlerdir. Hizmetlerin kamusal olması ise, faydası ülke geneline yayılmış ve bütün toplumun ortak çıkarı olan mal ve hizmetleri ifade etmektedir. Böylesi bir nitelik sergileyen bu hizmetleri devlet, genelde kamu yönetimi ve özelde ise kamu personeli tarafindan yerine getirmektedir. Kamu personeli ise kamusal nitelikteki faaliyetlerini kanun, tüzük, yönetmelik, yönerge, genelge gibi hukuksal metinler çerçevesinde gerçekleştirmektedir. Gerek kamu yönetiminin sunmuş olduğu mal ve hizmetlerin niteliği gerekse bu hizmetlerin dayandığ1 tüm bu hukuksal düzen için geçerli olan temel ilke ise kamu yararıdır (Özdemir, 2008, s. 180; Eryllmaz, 2015, s. 18). Görüldüğü üzere kamu yararı kamu yönetimi açısından oldukça önemli bir kavramdır.

Yapılan tanımlar ve açıklamalar incelendiğinde, kamu yararı kavramının temelde kamu yönetiminin gerçekleştirmiş olduğu eylem ve işlemlerde toplumsal faydayı göz önünde bulundurması ve bu amaç ile faaliyet göstermesi gerekliliği ön plana çıkmaktadır. Bu durum devletin ve kamu yönetiminin toplum tarafından meşru kabul edilmesinden hukuksal düzenin benimsenmesine kadar uzanan geniş bir süreci kapsamaktadır. Dolayısıyla kamu yararının devlet ve onun yürütme aygıtı olan kamu yönetimi tarafindan benimsenmesi gerekmektedir. Bu noktada kamu yaran kavramı ile adalet arasındaki ilişki kendisini göstermektedir. Zira Çeçen'e göre adalet kavramına amaç olarak bakıldığı zaman, toplumda özlemi çekilen, gerçekleşmesi istenen, gerçekleşmesine karşı çıkılan, değişmesi istenen tüm kararlar, davranışlar ve işlemler 
adalet çerçevesi içinde yer almaktadır (1993, s. 22). Dolayısıyla adalet kavramının ne olduğunun ortaya konması önem arz etmektedir.

\section{Adalet Kavramı}

Her zaman her yerde sözü edilen ve herkes tarafindan çeşitli fikirler öne sürülen adalet, yapılan tartışmalara ve sunulan düşüncelere rağmen henüz bir temele oturtulamamış ender kavramlardan biridir. $\mathrm{Bu}$ nedenle adalet kavramının ne olduğunu kimse tam olarak ortaya koyamamaktadır. Gerçeğin ne olduğunu belirten kesin bir yanıtın zamanımızda bile ortaya çıarılmadığı düşünülürse kavramın ne derece karmaşık bir yapida olduğu anlaşılmaktadır. Zorluğun temel nedeni ise çeşitli anlamların adalet kavramınca içerilmesinden kaynaklanmaktadır (Çeçen, 1993, s. 18).

Böylesi bir kavramın net bir tanımının ortaya konması elbette zordur. Lakin adalet kavramının ne olduğu ile ilgili yazın literatüründe çokça tanım bulunmaktadır. Dolayısıyla Eski Yunan düşünürlerinden günümüz düşünürlerine kadar gelinen süreçte adaletin ne olduğu ile ilgili birçok tanıma yer vermek mümkündür. Kavramın ne olduğunun ve nasıl bir içerik ihtiva ettiğinin anlaşılabilmesi açısından bazı tanımlara yer verilmesi ve özellikle yapılan bu çalışma ile ilişkilendirilmesi ayrıca önem taşımaktadır.

Kelime olarak Arapçada "adl” fiilinden türemiş bir isim olan adalet, Türk Dil Kurumuna göre "Yasalarla sahip olunan hakların herkes tarafindan kullanılmasının sağlanması, hak ve hukuka uygunluk, hakkı gözetme, herkese kendine uygun düşeni, kendi hakkı olanı verme, doğruluk" gibi anlamlara gelmektedir (www.tdk.gov.tr).

Adalet kavramının ne olduğunu sistematik bir şekilde ilk defa inceleyen kişi Platon'dur. Platon Devlet adlı eserinde adaleti bireysel yaşamdan toplumsal yaşama ve nihayetinde devlet yaşamına kadar incelemiş ve bu konuda çeşitli fikirler öne sürmüştür. Adaletin geniş kapsamlı bir kavram olmasından dolayı adalet ile ilgili birçok düşünsel yargı öne süren Platon, adaleti, temelde hak kavramı üzerinden incelemiş ve "her insana hak ettiği şeyi vermek" olarak tanımlamıştır (Platon, 2016, s. 14).

Platon'a yönelik eleştirilerini çalışmalarının merkezine koyan Aristoteles ise adalet kavramını eşitlik temelinde incelemiştir. Zira Aristoteles (2017, s. 92) Nikomakos'a Etik eserinde adaletin eşitlik olduğunu belirtmiştir. Buradaki eşitlik bireyin içinde bulunduğu duruma göre farkllılk göstermektedir. Yani Aristoteles, eşitlik temelinde incelediği adaletin her zaman eşitlik olmayacağını ifade etmiştir. Adalet eşitliktir, ama sadece eşit olanlar için eşitliktir. Yine adalet eşitsizliktir, ama eşit olmayanlar için eşitsizliktir. Dolayısıly herhangi bir şeyin adaletli olup olmadığı, bireye ve içinde bulunduğu duruma bağlı olarak değişmektedir. Aristoteles adalet kavramının genel bir açıdan incelenmesinin doyurucu ve yeterli olmayacağı sonucuna ulaşmış ve adalet kavramının farklı açlardan değerlendirilmesi gerektiğine inanmıştır. Dolayısıyla Aristoteles adaleti dağıtıcı ve denkleştirici adalet olmak üzere iki farklı şekilde incelemiştir. Aristoteles, dağıtıcı adaletin bölüştürülebilir şeyler üzerinde temellenebileceğini belirtirken, denkleştirici adaletin ise taraflar arasındaki gayri adil bölüşümü giderici bir fonksiyon gördüğünü vurgulamaktadır. Aristoteles'in adalet konusundaki bu ayrımı ve düşünceleri günümüzde güncelliğini sürdürmeye devam etmektedir (Güriz, 1990, s. 13; Demir, 2010, s. 451; Küçük, 2008, s. 91).

Antik Yunan düşünürleri tarafindan ortaya konan adalet anlayışının benzeri Orta Çağ döneminde yaşayan düşünürlerce de benimsenmiştir. Çiçero ve Thomas Aquinas gibi büyük düşünürler, Eski Yunan düşünürlerinin benzeri bir düşünce ile adalet kavramlarını incelemiş ve adaleti hak kavramı ile ilişkili bir şekilde tanımlamışlardır. Bu anlayış ile adalet, her insana hak ettiğinin verilmesi şeklindedir (Kocaoğlu, 2014, s. 10). Bu dönemde İslam dünyasının önde gelen düşünürlerinde olan Kindi, Farabi ve İbn Sina gibi önemli İslam düşünürleri de adalet konusunda önemli fikirler öne sürmüşlerdir. Kindi adaleti "gerekli olanı istemek ve başkasına eziyet etmemek" şeklinde tanımlamıştır (Çubukçu, 1972, s. 37). Farabi adaleti, herkesin hak ettiği oranda şeye sahip olması ve insanlar arasında paylaştırılmış iyi şeylerin şehir halkı için baki kılınması olarak tanımlamıştır (Farabi, 1987, s. 54). İbn Sina için ise adalet, orta olmaktır. Bu bağlamda adalet zulme uğrama ile zulüm etme arasında orta bir davranıştır (2016, s. 46).

Adaletin günümüz çağındaki görünümü incelendiğinde ise John Rawls ve Robert Nozick’in adalet tanımlarına yer vermekte fayda vardır. Rawls adaleti hakkaniyet temelinde değerlendirmiş ve her şeyin temeli olarak ifade etmiştir. Ona göre adalet, "insanlar arasındaki işbirliği için gerekli koşuldur". Nozick'in adalet anlayışı ise "hak ve özgürlük temelinde bireyin biricikliğinin garanti edilmesi"dir (Rawls, 1971, s. 52; Kocaoğlu, 2014, s. 38).

Adaletin tarihi süreç içerisindeki anlamı, ihlal edilen hakkın mahiyetine göre şekillenmektedir (Kılıç, 2014, s. 9). Bu durum adalet konusunda fikirler öne süren düşünürlerin fikirsel ayrrllklar yaşamalarına ve 
adaletin farklı anlamlarının ortaya çıkmasına neden olmuştur. Adalet ile ilgili yapılan çalışmalar incelendiğinde adaletin farklı açılardan ele alındığı ve bir temele oturtulmaya çalışıldığı görülmektedir. Dolayısıyla adaletin bazen bireysel erdem, bazen toplumsal bir değer ve bazen de devlet yaşamının temeli olduğu sonuçlarına varılmıştır.

Adalet, hangi anlamda kullanılırsa kullanılsın, tarihin tüm dönemlerinde en üstün erdem olarak kabul edilen ve varlığı ile ahlaki erdemlerin anlam kazanmasını sağlayan, insanın hep yanı başında bulunan ve insanlara hakkın, düzenin ve mutluluğun kapılarını aralama imkanı sunan temel olgudur. Gerek bireysel anlamda nefsin yetkinliğe ulaşmasında, gerekse toplumsal anlamda düzenin tesis edilmesinde yegane güç olan adalet, kamu yönetimi açısından mutlaka sağlanması gereken çok önemli bir değerdir. Adalet, topluma mal ve hizmet sunma hususunda devletin en önemli organı olan kamu yönetiminin başarllı bir şekilde faaliyet göstermesi, toplum tarafindan meşru kabul edilmesi ve insanların kamu yönetimine duydukları güvenin tesis edilebilmesi için bir gerekliliktir. $\mathrm{Bu}$ anlayıs kamu yönetiminin faaliyetleri ile somutlaşmaktadır. Burada dikkat edilmesi gereken husus kamu yönetiminin faaliyetlerini icra ederken kamu yararını dikkate alıp almadığıdır. Zira vatandaşlar adına faaliyet gösteren kamu yönetiminin eylem ve işlemlerinde kamu yararından bağımsız bir şekilde faaliyet göstermesi hem kendi varlık nedenine hem de adaletin doğasına aykırı bir davranışıtır. Dolayısıyla çalışmanın bir sonraki bölümünde kamu yönetiminde kamu yararının sağlanabilmesinde adaletin nasıl bir öneme sahip olduğu incelenecektir.

\section{Kamu Yönetiminde Kamu Yararının Gerçekleştirilmesinde Önemli Bir Kavram Olarak Adalet}

Kamu yönetimi, halkın ihtiyaçlarını karşılanması için bireylere ya da topluma hizmet sunmak amacıyla faaliyet göstermektedir. Kamu yönetimi bu hizmetlerin sunumu sırasında bireyi değil, bireylerin içinde bulunduğu toplumun bir kısmını ya da tüm toplumu dikkate almaktadır. Toplumsal çıkarlar ile bireysel çıkarların çakıştı̆̆ durumlarda kamu yönetimi toplumsal çıkarlardan yana karar vermektedir (Bozkurt vd., 2008, s. 133). Bu durum kamu yararı açısından genel menfaatlerin özel menfaatlerden üstünlügüne dayanmakla birlikte bireysel çıkarlar ile toplumsal çıkarlar arasında kaçınılmaz bir ilişki ve mücadeleyi sonuç vermektedir.

Bireysel menfaatler ile toplumsal menfaatler arasındaki ilişki kamu yararının belirlenmesi açısından oldukça önemlidir. Zira temel problem bireysel çıkarların mı yoksa kamusal çıarların mı dikkate alınması gereğinde yatmaktadır. Bireysel çıkarlar ile kamusal çıkarlar arasındaki ilişkiler genel olarak üç farklı görüş çerçevesinde değerlendirilmektedir. Bunlardan ilki, Platon, Aristoteles, Thomas Aquinas, Jean Jacques Rousseau ve FriedrichHegel'in düşüncelerine dayanan ve bireysel çıkarlar ile kamusal çıarların sürekli bir çatışma içerisinde bulunduğu düşüncesiyle, kamusal yararın dikkate alınması gerektiğini ifade eden görüştür. İkincisi, John Locke, Thomas Hobes, Jeremy Bentham, David Hume ve John StuartMill gibi klasik liberal teorisyenlerin görüşleriyle şekillenen ve kamusal çıkarların bireysel çıkarların toplamı olduğu düşüncesine dayan görüştür. Üçüncüsü ise John Rawls gibi siyasi liberaller ile Joseph Raz gibi faydac1 düşünürlerin görüşüne dayanan, bireyselliğe vurgu yaparak kamu yararını bir toplumun ortak çıkarlarına dayandıran yaklaşımdır (Uyanık, 2013, s. 23-14).

Bu görüşler adalet açısından incelendiğinde, her bir görüşün farklı bir adalet perspektifine dayandığ1 görülmektedir. Kamu yararının bireysel çıkarlardan üstün olduğu görüşüne dayanan temel düşüncede, örneğin Rousseau'nun Toplum Sözleşmesi'ne (2017, s. 34) göre, kamu yararı temel amaçtır ve kamu yarar1 adaletlidir. Kamu yararının bireysel çıkarların toplamı olduğuna dayanan ikinci görüşe göre, örneğin adalet düşüncesini fayda temelinde inceleyen Mill’in düşüncesi ile, "herkese hakkını vermek ve sayg1 göstermek" olan adalet, kişisel yararın en açık biçimde göstergesidir (Çeçen, 1993, s. 56). Bu mantık ile bireysel çıkarlar ve bireysel çıarların toplamı olan kamu yararı da adaleti ifade etmektedir. Üçüncü görüşü savunanları ise Rawls'ın düşünceleri ile ifade etmek gerekirse, kamu yararının sınırı adalettir, bireysel hak ve özgürlükler toplumsal yarardan önce gelmektedir ve dolayısıyla bireysel hak ve özgürlükler kamu yararı adına feda edilemez (Çakır, 2017, s. 565).

Kamu yararı konusunda farklı adalet perspektifleri içeren bu görüşlerde temel problem bireysel fayda ile toplumsal fayda arasında yaşanmaktadır. Aslında bireysel çıkarların yeri geldiğinde toplumsal çıkarlar için feda edilip edilmeyeceği tarihsel süreç içerisinde birçok tartışmanın ve düşüncenin temelini oluşturan önemli bir problemdir. Esasen toplumsal anlamda adaletin sağlanmasında bireysel çıkarların göz ardı edilmemesi ve vatandaşların bir bütün olarak eşitlik temelinde değerlendirilmesi gerekmektedir. Lakin eşitliğin uygulanma şekli ve boyutu da adalet ile çelişir durumların yaşanmasına neden olabilmektedir. $\mathrm{Bu}$ nedenle kamu yararı açısından adaletin, temelde bireysel çıkarlar ve eşitlik açısından değerlendirilmesi gerekmektedir. 
İslam hukukundaki genel görüşe göre bireysel çıkarlar kamu yararı söz konusu olduğunda, varsa bedeli ödenmek kaydiyla, feda edilebilir (Aktan, 2001, s. 356). Lakin burada önemli bir husus bulunmaktadır. Normal şartlarda bireysel haklar toplumsal haklardan üstündür ve toplum adına bireyin nzzası bulunmaksızın hakkının feda edilmesi zulümdür (Nursi, 2013, s. 89). Gazali, bireysel bir hakkın toplumsal bir hak için feda edilebilmesi için zaruretin varlığını gerekli kılmıştır. Zarureti ise can, mal, akıl, din ve ırzın korunması olarak belirtmiştir. Ancak bunların korunması kaydıyla kamu yararının sağlanabileceğini, bunların zarara uğrayacağı yerde ise kamu yararının esas alınmasının zulme neden olacağını ifade etmiştir (Gazali, 1994, s. 333). Bu şartların sağlandığı durumlarda kamu yararı adına bireysel menfaatler ikinci planda kalmaktadır.

Günümüz Türk kamu yönetiminde kamu yararının bazı farklılıklarla birlikte yukanda bahsedildiği şekilde faaliyet gösterdiği söylenebilir. Çünkü kural olarak hukuk sisteminin temeli denkleştirici adalet düşüncesine dayanmaktadır. Türk hukuk sisteminde klasikleşmiş olan adalet düşüncesi de, hak edene hak ettiği kadarının verilmesini gerekli kılmaktadır. Günümüz çağında yer alan adalet düşüncesi hak ve ödev kavramı arasındaki dengede yer almaktadır. Ancak sosyal adalet ve dağıtıcı adalet düşüncesi, eşitlik düşüncesinden farklı olarak, toplumsal faydanın dikkate alınmasını gerektirmektedir. Dolayısıyla kamu yarar1 ile sosyal adalet veya dağıtıcı adalet düşüncesinin birbirlerini destekleyen teorik temele sahip olduğunu söylemek mümkündür (Uyanık, 2013, s. 56).

Günümüzde kamu yararı ile adalet arasındaki farkl1lıklardan dolayı, kamu yararı eşitliği bozacak nitelikte olsa da, kamu yararının meşruluk fikri adalete dayanmaktadır (Uyanık, 2013, s. 57). Bu açıdan bakıldığında kamu yararı hususunda bireysel çıkarlar ile toplumsal çıkarlar arasındaki ilişki, adalet doğrultusunda somutlaşmaktadır. Yani kamu yararının sağlanmasında adaletin esas alınması, bireysel çıkarlar ile toplumsal çıkarlar arasındaki dengenin sağlanmasında oldukça etkilidir. Aslında kamu yararı ile adalet arasındaki ilişki oldukça eski bir geçmişe sahip bulunan ender düşüncelerden de biridir. Öyle ki düşünceleriyle modern özgürlük idealinin temellerini oluşturan başta Stoikler ve Çiçero gibi kadim yazarlar için kamu yararı adalet ile aynı şeydir. Özellikle eserlerinde kamu yararına atıfta bulunarak, bundan barışın ve adaletin korunması şeklinde bahsetmişlerdir. Hatta 17. yüzyıla kadar James Harrington gibi düşünürler için kamu yararı, her türlü özel çıkarın ve tarafgirliğin hariç tutulmak suretiyle ortak çıarnn ve adaletin korunmasından başka bir şey değildi (Hayek, 1995, s. 22 Akt:Göven, 1998, s. 8). Dolayısıyla ifade edilebilir ki kamu yararı ile adalet, birbirlerinden ayrılmayan ve genellikle aynı kabul edilen bir geçmişe sahiptir.

Kamu yararı toplumsal çıkarların kabulünde eşitlik ilkesine göre hareket etmektedir. Yani bireyin ve toplumun refahı ve huzuru anlamına gelen kamu yararına dayanılarak bireyler arasında ayrım yapilmaması eşitlik ilkesini gerektirmektedir. Kanunlarla veya kamusal uygulamalarla getirilen kısıtlamaların toplumsal faydası bireyin uğrayacağı zarardan daha ağrı bastı̆̆ında, kamu yararından yana faaliyette bulunmak gerekmektedir. Eşitlik ilkesine aykırı bir şekilde yapılan farklı uygulamalar, kamu yararı amacıyla yapılmıssa, bunlar hukuka aykırı görülmemektedir. Yani bireyin haklı nedeni eşitsizliğe neden olsa da, düzenleme eşitlik ilkesine aykırı olarak değerlendirilmez (Serim, 1994, s. 16; Gözler, 2003, s. 277). Buradaki temel problem toplumun hepsinin eşit bir şekilde kabul edilmesinin adaletli bir tutum olup olmadığıdır.

Eşitlik adaletin önemli görünümlerinden biridir. Aristoteles’in eşitlik ve adalet konusundaki görüşleri eşitliğin hangi durumlarda adaletli veya adaletsiz olduğunu belirtme hususunda oldukça önemlidir. Aristoteles (2017, s. 96), adaleti eşitlik temelinde değerlendirirken, eşit kişilerin eşit şeylere sahip olmasını ve eşit olmayan kişilerin ise eşit olmayan şeylere sahip olması gerektiğini ifade etmiş ve bu durumun adalet olduğunu belirtmiştir. NasiruddinTusi (2016, s. 298) de yine adaletin bir şartı olarak, ortak yararın paylaştırılması hususunda bireyler arasındaki eşitliğin gözetilmesi ve herkesin istihkak ve istidadının dikkate alınması gerektiğini ifade etmiştir. Aslında Aristo ve Tusi’nin burada bahsettiği eşitlik bir oranı ifade etmektedir. Dolayısıyla koşulların gereğine göre nimetlerin ve külfetlerin farklılığı adaletin gereğidir (Serim, 1994, s. 15). Bu düşünce kamu yararı amacıyla faaliyet gösteren kamu yönetimi açısından önemli bir rehberdir.

Kamu yararı adalet temelinde değerlendirildiği zaman anlamlı hale gelmekte ve toplum nezdinde meşrulaşmaktadır. Kamu yönetimi bireye göre güçlü konumda bulunmaktadır. Kamu yönetimine kamu yararı amacıyla tanınmış olan yetkiler kamu yararı ile bağdaşmayacak bir şekilde kullanılabilir. Bunu önleyebilmek için kamu yönetiminin hukuk sınırları içinde kalması ve nesnelliğe önem vermesi gerekir (Bozkurt vd., 2008, s. 133). Bu durum adaleti gerekli kilmaktadır. Zira kamu yönetiminin sahip olduğu gücü kamu yararı açısından kullanabilmesi, gücün adil kullanımı ile yakından ilişkilidir. Böylesi bir anlayış 
kamu gücünün toplum tarafindan meşru kabul edilmesini de beraberinde getirmektedir. Unutmamak gerekir ki, adalet olmadan ne meşruiyet olabilir ne de gayri meşruiyet (Comte-Sponville, 2004, s. 78).

Günümüzde bireylerin, toplumların veya örgütlerin kendilerini oluşturan bireylerden farklı hedefler izledikleri, ilgili hedeflere ulaşmak için izlenen politikaların birbirlerinden farklı ve hatta birbirleriyle çeliştikleri görülmektedir. Kimi durumlarda kamu kurumlarının kamu yararı varsayımını kullandıkları halde, aynı konularda farklı kararlara ulaşarak birbirleri ile anlaşmazlı̆̆a düştükleri bir gerçektir (Akıllıŏlu, 1988: 9). Esasen bu durum kamu yararının muğlak yapısından kaynaklanmaktadır. Kamu yararı üzerine yapılan çalışmalarda da genellikle kavramın muğlak bir yapıda olmasından şikayet edilmiştir (Dik, 2005, s. 2). Kavramın sahip olduğu bu nitelik kamu yararının herkes tarafından anlaşılabilir düzeyde net bir şekle sokulmasını engellemekte ve farklı uygulamaların yaşanmasına mahal verebilmektedir. Bu durumun giderilebilmesi için adaletin kamu yararı açısından uygulanması gerekmektedir. Çünkü Aristoteles (2017, s. 82) adaletin tüm erdemleri kendisinde taşıyan yegane erdem olduğunu, herhangi bir şeyin kendi amac1 doğrultusunda kullanılmasını ifade ettiğini ve ne akşam yıldızının ne de sabah yıldızının adalet kadar muhteşem olmadığını belirtmiştir. Bu ifadeler aslında adaletin net bir kavram olduğunu ve hangi değer açısından kullanılırsa kullanılsın, o değere yalın bir hal katacağını ifade etmektedir. Dolayısıyla kamu yararının sahip olduğu muğlaklığın giderilmesinde ve kavramın somutlaşmasında adalet önemli bir yere sahiptir.

Teorik bakımdan kamu yararı yönetimsel takdir yetkisinin temel kaynağı olarak görülmektedir. Dolayısıyla kamu yararının etkin bir şekilde sağlanabilmesi için takdir yetkisinin genişletilmesi gerekmektedir (Öztürk, 1998, s. 84-85). Takdir yetkisi kamu yönetimi açısından gerekli ve önemli olan bir yetkidir. Çünkü tüm işlemlerin yasalar doğrultusunda gerçekleştirilmesi mümkün değildir (Kalabalık, 1999, s. 205). Kamu yönetimindeki geniş bir takdir yetkisi ise kamu görevlilerinin keyfi davranışlar sergilemesine neden olabilmektedir (Çevikbaş, 2006, s. 271). Bu durum kamusal kaynaklarının kamu yararı dışında kullanılmasına ve dolayısıyla zulme neden olabilmektedir. Çünkü adaletin dikkate alınmadan kullanıldığı bir yetkinin amacı doğrultusunda kullanılması zordur. Herkese hak ettiğinin verilmesi olan adalet, Farabi’nin (2001, s. 52) ifadeleriyle, herhangi bir şeyin kendi liyakatinin icabını ifa etmesidir. Bu ifade adaletin herhangi bir şeyin amacı doğrultusunda kullanılmasını da kapsayan geniş bir erdem olduğunu göstermektedir. Dolayısıyla kamu yönetiminin varlık nedenlerinden biri olan kamu yararının sağlanabilmesi için, takdir yetkisinin kullanılmasında adaletli davranılması gerekmektedir.

Kamu personeli normal şartlarda görevlerini yasalar çerçevesinde yerine getirmektedirler. Bu doğrultuda kamu görevlisinin temelde iki görevi bulunmaktadır. Bunlardan ilki yasaya saygılı ve bağlı bir şekilde faaliyet göstermeleri; ikincisi ise, yasaları eşitlik ilkesi doğrultusunda adaletle uygulamalarıdır. Vatandaşların kamu yönetimi konusunda dert yandığı önemli bir husus eşitlik ilkesinin ihlal edilmesi ve uygulayıcıların adaletsiz davranışlarıdır (Serim, 1994, s. 15). Dolayısıyla kamu yararının beklendiği şekilde uygulanabilmesi için kamu personelinin herkese, adaletin gerektirdiği şekliyle, eşit bir şekilde davranması gerekmektedir.

Kamu personelinden en genel anlamı ile görevlerine uygun bir şekilde karar almaları ve bu kararları kamu yararı doğrultusunda uygulamaları beklenmektedir. Bu beklentiler içerisinde görev yapan kamu görevlileri arasında birçok ikilem ve açmaz ortaya çıkabilmekte ve bu durum kamu görevlilerinin kararlarını ve uygulamalarını etkileyebilmektedir (Usta, 2011, s. 45). Bu açmazlardan en önemlisi hiç şüphesiz kamu personelinin kamu yönetimini ve hizmetlerini kamu yararı yerine kendi menfaatleri yönünde kullanmasıdır. Platon'a (2016, s. 35-36) göre, yönetimde bulunan hiç kimse, bir yönetici olarak görevinde kalmaya devam ettiği süre içerisinde kendi çıarlarına uygun olan şeyleri gözetemez. Kamu personeli, sadece yönetiminde bulunan kişilerin faydasını gözetmek durumundadır. Öyle ki konuştuğu her kelimede ve yaptığı her şeyde yalnızca bunu göz önünde bulundurmalıdır.

Kamu personelinin bireysel menfaatlerini kamusal menfaatlerden önce tutması adaletsizliktir. Diğer bir ifade ile adaletin bulunduğu yerde menfaat, menfaatin bulunduğu yerde ise adalet bulunmaz. Konfüçyüs adalet ile menfaat arasındaki ilişkiye dikkat çekerken "yüksek insan adaleti; alçaklar da menfaati anlar" demiştir. Bu durum liyakatin de önemli bir etken olarak ortaya çıkmasını sağlamaktadır. Defterdar Sarı Mehmet Paşa (1969, s. 40), kamu görevinin ehil olmayan kişilere verilmesini, kamusal kaynakların yağmalanmasına ya da bireysel menfaatler doğrultusunda kullanılmasına müsaade etmek olarak değerlendirmiştir. Liyakat ise adalet ile gerçekleşebilen veya adaletin en güzel tezahür şekillerinden biri olan önemli bir olgudur. Dolayısıyla adalet ile hem menfaatlerinden sıyrılmış bir kamu personeli hem de liyakati gözeten bir kamu yönetiminin oluşumu ve nihayetinde kamu yararının başarılı bir şekilde gerçekleştirilmesi 
sağlanabilecektir. Esasen kamu yönetiminde bireysel çıkarlar yerine toplumsal çıkarların öne çıkarılması, adaletli bir devlet yapısının da ortaya çıkmasını sağlayacaktır. Zira Platon (2016, s. 170), tüm vatandaşların çıkarlarının gözetildiği bir devlet yapısının adaleti doğuracağını ifade etmiştir.

\section{Tartışma, Sonuç ve Öneriler}

Kamu yönetimi vatandaşlara karşı eşit bir şekilde yaklaşan ve karar ve uygulamalarında nesnel olması gereken devletin çok önemli bir organıdır. Kamu yönetiminin bu tutumu kamu yararının sağlanabilmesi açısından oldukça önemlidir. Lakin uygulamada bazen adaletin ihmal edildiği ve bireysel menfaatlerin kamu yararından önce tutulduğu görülmektedir.

Ortak ihtiyaçlarını gidermek amacıyla bir araya gelen vatandaşların kamu yönetiminden en önemli beklentisi, bu ihtiyaçlarının giderilmesidir. Kamu yönetiminin kendisinden beklenen bu amacı gerçekleştirebilmek için kamu yararı doğrultusunda faaliyet göstermesi bir zorunluluktur. Bunun sağlanabilmesi için kamu yönetiminde adaletin bir değer olarak inşa edilebilmesi gerekmektedir. Çünkü kamu yararı adaleti gerekli kılan ve adalet ile anlamlı hale gelen bir olgudur.

Kamu yararının sağlanmasında adaletin gerekli kılındığı bu çalısmada birçok önemli sonuca ulaşılmıştır. Öncelikle ifade etmek gerekir ki, toplumsal çıkarlar belli şartlar altında bireysel çıkarlardan üstündür. Bireysel çıarların kamu yararından önde tutulması kamu yönetimi açısından adaletsiz bir durum oluşturmaktadır. Dolayısıyla kamu yönetiminin kamu yararı doğrultusunda faaliyet göstermesi adaletin gereğidir.

Kamu yönetimi bireylere göre güçlü konumda bulunmaktadır. Bu durum kamu yönetiminin bazen kamusal yararı göz ardı etmesini sonuç verebilmektedir. Bunun engellenebilmesi için kamu yönetiminin sahip olduğu gücü adalet doğrultusunda kullanması gerekmektedir. Bu durum kamu yönetiminin elinde bulundurduğu gücün toplum tarafindan meşru kabul edilmesinin de yoludur.

Kamu yararı kavram olarak muğlak bir yapıya sahiptir. Dolayısıyla kamu yönetiminde alınan kararlarda ve uygulamalarda bazen benzer durumlar için farklı kararların alınabildiği ve kamu yararının zarar gördüğü görülmektedir. Kamu yararının belirsizliğinden kurtulması için açık bir nitelik ihtiva eden adalet olgusunun kamu yararında bir öncü olarak kabul edilmesi gerekmektedir.

Kamu yararının sağlanabilmesi için kamu yönetiminde takdir yetkisi kullanılmaktadır. Takdir yetkisinin göreceli bir nitelik arz etmesi bu yetkinin amacı doğrultusunda kullanılmasını engelleyebilmektedir. Aynı zamanda takdir yetkisi kamu personeli tarafindan bazen kişisel çıkarlar amacıyla da kullanılabilmektedir. Her iki durumda da vatandaşlar adına faaliyet göstermesi gereken kamu yönetimi, kamu yararından sapabilmektedir. Bunun engellenebilmesi için takdir yetkisinin kullanılmasında mutlaka adaletli davranılması gerekmektedir. Çünkü adalet, doğası itibariyle yetkilerin amacı doğrultusunda kullanılmasını sağlayan temel erdemdir.

\section{Kaynakça}

Akıllığlu, T. (1988). Kamu yararı kavramı üzerine düşünceler. İdare Hukuku ve İlimleri Dergisi,9(1-3), 3-15.

Aktan, H. (2001). İstimlak. Türkiye diyanet vak.fi Islam ansiklopedisi,23, 364-366.

Aristoteles, (2017). Nikomakhos'a etik(Çev: S. Babür). Ankara: Bilgesu Yayınları.

Aydın, A. H. (2016). Kamu yönetimine giriş. Ankara: Seçkin Yayıncılık.

Birinci, G. (2009). Kamu etiği ve insan hakları. Felsefe ve Sosyal Bilimler Dergisi, 8, 123-144.

Bozkurt, Ö., Ergun, T., ve Sezen, S. (2008). Kamu yönetimi sözlüğü. İçinde S. Sezen (Edt.). Ankara: TODAİE Yayınları. Comte-Sponville, A. (2004). Büyük erdemler risalesi (Çev: I. Ergüden). İstanbul: İstanbul Bilgi Üniversitesi Yayını.

Çakır, M. (2017). Geçmişten günümüze "sosyal adalet". International Journal of Social Sciences and Education Research, 3(2), $560-572$.

Çeçen, A. (1993). Adalet kavramı. İstanbul: Gündoğan Yayınları.

Çevikbaş, R. (2006). Yönetimde etik ve yozlaşma. Atatürk Üniversitesi İktisadi ve İdari Bilimler Dergisi,20(1),265-289.

Çubukçu, İ. A. (1972). İslam düsüncesi hakekında araştırmalar. Ankara: Ankara Üniversitesi İlahiyat Fakültesi Yayınları.

Defterdar Sarı Mehmet Paşa, (1969). Nesayib'ül Vü̈zera V'el Ümera.Devlet adamına öğ̈̈tler(Çev: H. R. Uğural). Ankara: Türk Tarih Kurumu Basımevi.

Demir, G. Y. (2010). Bir metafor olarak adalet. İsmail Serin (Ed.), Birinci Uluslararası Felsefe Kongresi Bildiriler Kitabı, Bursa: Uludağ Üniversitesi Yayını,ss. 451-459

Dik, E. (2005). Kamu yararı anlayışında değişim baskısı. Mustafa Kemal Üniversitesi Sosyal Bilimler Enstitüsü Dergisi,2(4), ss. 1-18.

Erdoğan, M. (2013). Anayasal demokrasi. Ankara: Siyasal Kitabevi.

Eryılmaz, B. (2015). Kamu yönetimi. Kocaeli: Umuttepe Yayınları. 
Farabi, (1987). Fusulü'l-Medeni. Siyaset Felsefesine Dair Görüşleri (Çev: H. Özcan). İzmir: Dokuz Eylül Üniversitesi Yayınlar1.

Farabi, (2001). El-Medinetü’l Fą̧la(Çev: N. Danışman). Ankara: Milli Eğitim Bakanlı̆̆1 Yayınları Bilim ve Kültür Eserleri Dizisi.

Gazali, (1994). El-Mustasfa.Islam bukukunda deliller ve yorum metodolojisi 1(Çev: Y. Apaydın). Kayseri: Rey Yayıncilık.

Göven, Y. (1999). Kamulaştırma işlemlerinde kamu yararı. Dumlupınar Üniversitesi Sosyal Bilimler Dergisi,1, 247-262.

Gözler, K. (2003). İdare bukuku II. Bursa, Ekin Yayınları.

Güriz, A. (1990), Adalet kavramı. Anayasa Yargısı Dergisi,7, 11-20.

Hayek, F. A. (1995). kanun, yasama faaliyeti ve öggürlük II(Çev: M. Erdoğan). İstanbul: İş Bankası Kültür Yayınları.

İbn Sina, (2016). Risale Fi ‘İlmi’l-Ahlak.İbn Sina’nın "Risale Fi ‘İlmi’l-Ahlak” Risalesinin Takdim, Tahkik ve Çevirisi (Çev: F. Toktaş).Dokuz Eylül Üniversitesi İlahiyat Fakültesi Dergisi, 4, 7-52.

Kalabalık, H. (1999). İdare hukukunda takdir yetkisi kavramı ve benzer kurumlarla karşılaştırılması. Gaži Üniversitesi Hukuk Fakültesi Dergisi, 1(2), 205-232.

Keleş, R. (2000). Kamu yarar üzerine.Betül Çotuksöken ve Doğan Özlem (Ed.), Bedia Akarsu Armağanı, İstanbul: İnk1lap Kitabevi.

Kılıç, H. (2014). Adalet: güç savașında denge noktası. İstanbul: Beta Yayınları.

Kocaoğlu, M. (2014). Robert nozick: adalet teorisi ve temel kavramlar. Ankara: İmaj Yayınevi.

Koç, K. A. (2014). Kamu yararı açısından yeni medya. XVI. Akademik Bilişim Konferansı Bildirileri, Mersin.

Küçük, A. (2008). Adalet kavramı ve adalete ilişkin bazı teoriler. Muhafąakar Düşünce Dergisi, 15, 91-121.

Nursi, S. (2013). Mektubat. İstanbul: Yeni Asya Yayınlar1.

Özdemir, M. (2008). Kamu yönetiminde etik. Zonguldak Karaelmas Üniversitesi Sosyal Bilimler Dergisi, 4(7), 179-195.

Öztürk, N. K. (1998). Kamu yöneticilerinin kararlarında etik değerler. Amme İdaresi Dergisi, 31(2), 81-92.

Parlak, B. ve Doğan, K. C. (2016). Kamu yönetimi. İstanbul: Beta Yayınları.

Platon, (2016). Devlet(Çev: E. Alagöz). Ankara, Panama Yayınları.

Rawls, J. (1971). A teory of justice. Massachusetts: Original Edition.

Rousseau, J. J. (2017). Toplum sözleşmesi. İstanbul: Türkiye İş Bankası Kültür Yayınları.

Saraç, O. (2002). Kamu yararı kavramı. Maliye Dergisi, (139), 16-26.

Serim, B. (1994). Yasa önünde eşitlik ilkesi. Amme İdaresi Dergisi, 27(3), 13-25.

Sezer, Ö. (2008). Kamu hizmetlerinde müşteri(vatandaş) odaklllık: Türkiye kamu hizmeti anlayışı açısından bir değerlendirme. Zonguldak Karaelmas Üniversitesi Sosyal Bilimler Dergisi, 4(8), 147-171.

Tusi, N. (2016). Ablak-ı Nasıri(Çev: A. Gafarov ve Z. Şükürov). İstanbul: Litera Yayıncılık.

Türk Dil Kurumu güncel Türkçe sözlük içinde. Erişim adresi: http://www.tdk.gov.tr/index.php?option=com_gts\&arama=gts\&guid=TDK.GTS.5b59a963dfdb24.96189621, 18.07.2018

Usta, A. (2011). Kuramdan uygulamaya kamu yönetiminde etik ve ahlak, Kahramanmarass Sütçü İmam Üniversitesi İktisadi ve İdari Bilimler Fakültesi Dergisi,1(2), 39-50.

Uyanık, H. (2013). Ekonomik kamu yarar kavrammm türk idare bukukundaki anlam ve islevi. İstanbul: On İki Levha Yayincilik.

Yayla, Y. (2010). İdare bukuku. İstanbul: Beta Yayınları.

\section{EXTENDED ABSTRACT}

Public interest is one of the most important concepts that has been tried to establish a foundation in the historical process and that has been studied much one what the concept is. The concept of public interest, which is considered by many thinkers as the main element in the management of the state and the evaluation of the managers, is a concept discussed in many areas. However, there is no unity in terms of its definition and rather different views are suggested about the term. Therefore, public interest includes a quality that differs according to time, place, clients, and type of service. There are mainly two reasons for this. The first is that the concept of public interest is a comprehensive concept that transcends law and management. Furthermore, the concept is examined in areas such as morality, philosophy, and sociology. Another reason is that the boundaries of the concept are not clear and have a very flexible structure. Today, the concept of public interest has expanded its scope in line with human needs by constantly renewing itself and has developed in the changing world despite its diversity and uncertainty.

As a concept, public interest can be defined as a basic and general goal oriented towards the actions and processes of public administration and for the protection of the interests of some or all of society. The public interest represents the common interests of a community. Taking into consideration the common needs of citizens in all administrative transactions is a fundamental necessity of public interest. This also goes for public administration. 
Public administration means that the state uses all its resources efficiently in order to provide public services in accordance with their purposes. In this sense, public administration is the means of conducting the duties of the state and operating the necessary processes and consists of the structure and activities of the state's executive power.

Exactly "what the public administration is" related to the knowledge of "what its purpose is". The main objective of public administration is to provide the most efficient use of resources at hand by the officials in order to offer the public services expected by the citizen. In a broader sense, the aim of public administration is to protect the public order and social peace which constitutes the scope of the state's final and fundamental duties, to ensure justice, to lead the youth, to protect the society and individuals against insecurity and diseases, to regulate the interests and group conflicts by preventing, in short, providing the citizen a good life.

The public interest is an important concept that is directly influential in the fulfillment of the actions and procedures of public administration and therefore legitimately accepted by the society on behalf of the citizens. Public interest, which is a broad concept, has been one of the main objectives of states in every period of history. Because the basic reason for the state and the public administration, which are the performers of the people who come together in order to meet their common needs, is the public interest.

The success of public administration arises in the consideration of the public interest. This brings with it the obligation of the public administration to take into account the public interest in all transactions. The realization of public interest by public administration depends on the concept of justice.

Justice basically refers to granting the right to those who deserve justice. Justice is the matter of fact what is appropriate for law and equality. Justice is the realization of rights and law. Justice is to treat everyone and everything in accordance with what they deserve.

Justice is the fundamental fact that is considered as the most superior virtue in all periods of history and that makes the existence of moral virtues gain meaning, which is always at the side of the human being and provides the opportunity for people to open the doors of right, order, and happiness. Justice, which is the only power to reach the competence of the personality in the individual sense and to establish order in the social sense, is a very important value that must be provided in terms of public administration. Justice is a requirement for the successful functioning of public administration, which is the most important body of the state in providing goods and services to the society, for the legitimate acceptance of the public administration by society and for the establishment of trust of people in the public administration. This perceptive is embodied by the activities of public administration. The issue to be considered here is whether the public administration takes into account the public interest in carrying out its activities. Because the public administration, which operates on behalf of citizens, operates independently of public interest in the actions and transactions, it is a violation of both the cause of its existence and the nature of justice.

Justice is the fundamental fact that ensures the realization of public interest. Because justice is a broad concept, justice refers to the use of anything for its purpose. It is through justice that public administration, whose main purpose is the public interest, achieves its purpose. In a management where justice is not taken into consideration, it is difficult to observe the common needs of citizens and this prevents the provision of public benefits. Therefore, justice must be adopted as a fundamental value in all actions and operations of public administration. 